\title{
ROLE OF ICT IN FOSTERING THE PERFORMANCE OF EDUCATION SECTOR OF AFRICA
}

\author{
${ }^{1}$ Muhammad Zulqarnain Siddiqui, ${ }^{2}$ Qazi Shahab Azam and ${ }^{3}$ Hira Beenish \\ ${ }^{1}$ School of Science and Engineering, Malaysia University of Science and Technology, Malaysia \\ zulqarnain.siddiqui@pg.must.edu.my \\ ${ }^{2}$ Department of Computer Science, Iqra University, Karachi, Pakistan \\ shahab.azam@iqra.edu.pk \\ ${ }^{3}$ Department of Computer Science, PAF KIET, Karachi, Pakistan \\ Hira@pafkiet.edu.pk
}

\section{ABSTRACT}

Education plays vital role in development and progress of under developed countries. This research paper proposes effective mechanism for the promotion of education by use of ICT in all parts of Africa. Monitoring is another aspect for the delivery of quality education at all levels. Keeping in mind all the aspects including poverty, promotion of education at all levels should be addressed on priority basis. Adaptability of technology and its effectiveness towards betterment should be highlighted using different approaches. Integrating different education monitoring bodies on a platform would benefit Government, management of institutions, donor agencies and general public of the area.

\section{KEYWORDS}

ICT, Education, Integrated systems, Data engineering

\section{INTRODUCTION}

Education sector is the backbone of a nation and is the basis for conception of a civilized society. In order to improve the overall performance of this sector it is essential to incorporate the use of the newly introduced technologies in it such as Information and Communication technology (ICT). ICT helps to reduce operational inefficiencies of an institution, ensures timely availability of information, increases its decision making abilities in areas that are most

crucial for its sustenance so that better educational provisions can be made.

ACRID 2017, June 20-21, Victoria Falls, Zimbabwe

Copyright (C) 2017

DOI 10.4108/eai.20-6-2017.2270056 
ICT has now become an integral part of lives of many individuals and is providing economic, social and educational benefits to the nations. It enables us to transfer, storage, retrieve and process information in the most efficient manner.

Many researches have been conducted researches regarding the role of ICT in education but most of them have focused on the aspect of ICT creating a better learning environment for the students and benefiting the teachers in improve their overall teaching experience by keeping themselves updated with the current technologies. But none have discussed its usage in the education sector for the purpose of planning and forecasting.

Having the aim of bringing transparency in the educational system this research focuses on creating an integrated data bank for educational sectors of underdeveloped countries which is a combination of information technology and statistics. This system will involve data regarding students, faculty, examination, fee packages, curriculum and admissions. This system could be viewed by government, corporate, educational boards, educational institutions, guardians and students. Through the initiation of this system interconnection between these entities will be increased.

It will help the government in budget allocation and planning for the educational sector, it will help educational boards to monitor the performance of public and private educational institutions, help guardians to keep a track of their child's performance, educational institutions to view their own consolidated reports and manage their performance, will help corporate to get bulk data about graduates directly from the system and will help students to view their progress even for the ongoing semester or year.

It will help to bring uniformity and improve the internal efficiency of the educational systems of underdeveloped countries. It will enable cross-border information sharing that includes sharing of student's overall educational record with across the border, college or university in case an individual is applying to get admission there and same data can be shared with that country's government for the issuance of student visa. 


\section{LITERATURE REVIEW}

Education system in Africa is based on two tiers that are looking after the basic schooling and higher education. Different provinces has different monitoring agencies governed by these two National bodies Department of Basic Education (DBE) and Department of Higher Education and Training (DHET).

Following the education system of Africa:

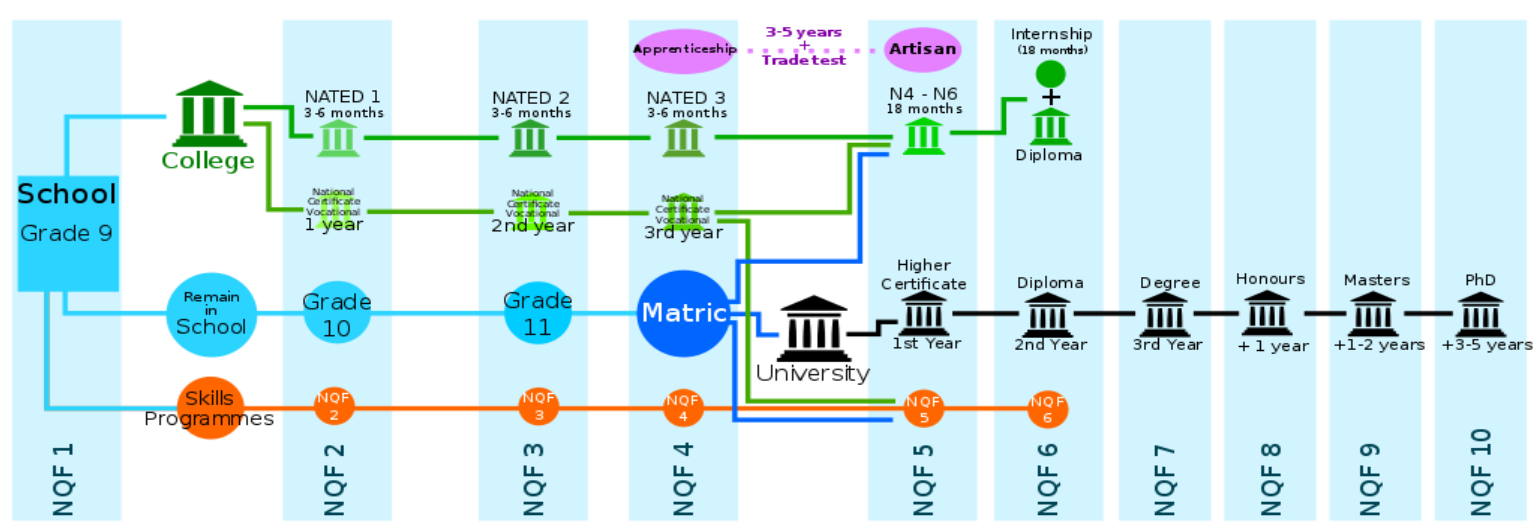

A graph mapping out the National Qualification Frameworks (NQF) - Source Wikipedia

Developing and developed countries are continuously updating themselves and growing rapidly but on the other hand underdeveloped countries are not even able to sustain their performance. The only way for them to survive in the current competitive environment and to compete globally is by strengthening their education sectors.

The educational system of these countries is still managing most of its operations manually which is a time consuming, chaotic and erroneous process. Attendance and marks are being recorded manually and results are revealed to the students after final compilation that is done at the end of the semester in universities and at the end of year in schools and colleges due to which there is a chance of manipulation in grades and marks till the issuance of final mark sheet or transcript. Educational boards follow a specific curriculum that is to be taught in all the schools, colleges and universities but there is no system to monitor the uniformity of curriculum therefore educational institutions mostly deviate from the stated curriculum. Institutional performances are evaluated through visits which are announced couple of months earlier due to which institutions can get an opportunity to prepare fake reports till the time of visit. There is no system that could view the actual performance and stature of the institute. Guardians get to 
know about their child's academic performance in school through annual teacher's meeting when the overall session has ended and there is nothing that the parents can do about their child's performance, they just get to know about the feedback. Whereas colleges and universities bear no responsibility of updating parents about their child's performance and they get to know about it through final mark sheet and transcript.

Currently there is no system through which government of underdeveloped countries can monitor the performance of their education sectors and there is no system through which complete statistical data of education records on individuals can be gathered. This is the reason why allocation of budget for the education sector in these countries is not done in accordance to the requirement.

Corporate have to go through a long process in order to gather curriculum vitas of graduate students and scrutinize candidates for a specific job. There is no proper system from where all the data regarding graduates can be extracted.

Educational institutions, educational bodies, guardians, corporate and government are presently not linked together.

Education sector of underdeveloped countries can perform efficiently with the proper use of ICT as it is a factor that brings significant change in the society and economy of a country.

Methodology

It is proposed to design and develop a centralized learning management that would be integrating all the institutions at both levels managed by DBE and DHTE. One of the limitations in productive outcome of this system is adaptability. In order to convince the targeted audience including students, parents and faculty / teachers should be motivated by planning week long activities highlighting the importance of ICT in life. According to Internet World Stats, Internet usage in Africa is about $28.7 \%$ of total population. 


\section{Internet Usage Statistics for Africa}

( Africa Internet Usage and 2016 Population Stats )

\begin{tabular}{|l|l|r|r|r|r|r|}
\hline \multicolumn{7}{|c|}{ INTERNET USERS AND POPULATION STATISTICS FOR AFRICA } \\
\hline \multicolumn{1}{|c|}{ AFRICA REGION } & $\begin{array}{c}\text { Population } \\
\text { (2016 Est.) }\end{array}$ & $\begin{array}{c}\text { Pop. } \% \\
\text { of World }\end{array}$ & $\begin{array}{c}\text { Internet Users, } \\
\text { Latest }\end{array}$ & $\begin{array}{c}\text { Penetration } \\
\text { (\% Population) }\end{array}$ & $\begin{array}{c}\text { Internet } \\
\%\end{array}$ & $\begin{array}{c}\text { Facebooks } \\
30-J u n-2016\end{array}$ \\
\hline Total for Africa & $1,185,529,578$ & $16.2 \%$ & $340,783,342$ & $28.7 \%$ & $9.3 \%$ & $146,637,000$ \\
\hline Rest of World & $6,154,629,914$ & $83.8 \%$ & $3,335,041,471$ & $54.2 \%$ & $90.7 \%$ & $1,532,796,530$ \\
\hline WORLD TOTAL & $\mathbf{7 , 3 4 0 , 1 5 9 , 4 9 2}$ & $\mathbf{1 0 0 . 0} \%$ & $\mathbf{3 , 6 7 5 , 8 2 4 , 8 1 3}$ & $\mathbf{5 0 . 1} \%$ & $\mathbf{1 0 0 . 0} \%$ & $\mathbf{1 , 6 7 9 , 4 3 3 , 5 3 0}$ \\
\hline
\end{tabular}

Smart phone users are increasing in Africa that is the attractive part for the validation of this system. The trend of smart phone users is increasing and is expected to grow at rapid pace in upcoming years. According to Statista ${ }^{[23]}$ there will be significant growth in this industry.

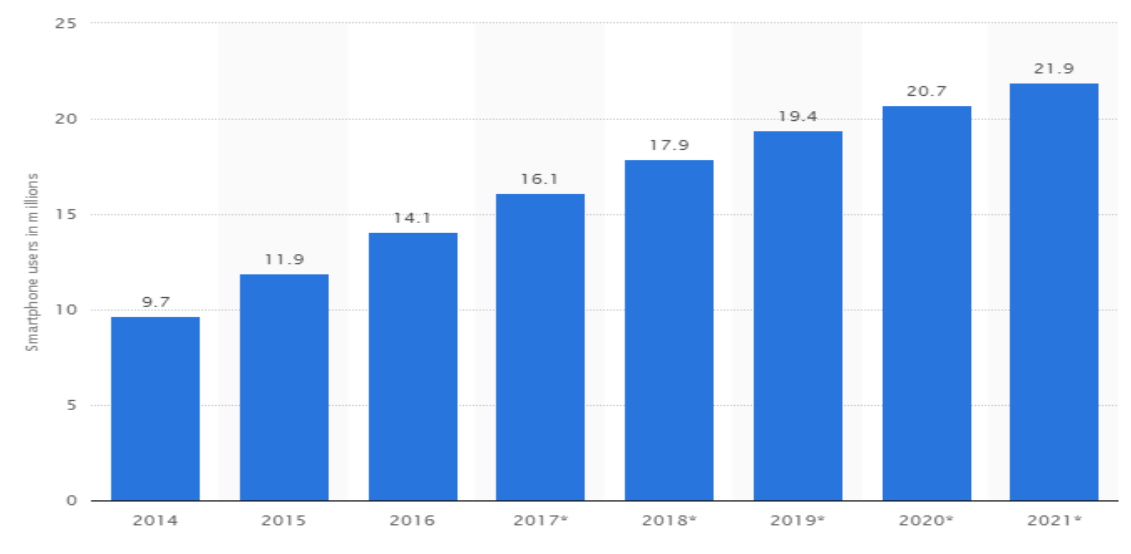

Since the adaptability of ICT tools are increasing in Africa, this might be the right time to introduce and educate the public on importance of the ICT in education for their well-being.

Initially, some of the potential institutions of both public and private sectors managed by DBE and DHET will be targeted for the deployment of system. Ofcourse the role of Education Ministry for enforcement of this national learning management system will be important. Once the system that contains all the related modules (including admissions, smart attendance, examinations, accounts, progress reports etc.) are deployed, staff will be trained for populating real time data. Data will be collected automatically in the process of system deployment. As when institutions will start incorporating the system in their work processes and start working on it information will automatically be updated in the data bank and can be viewed by all the individuals linked with the system. Statistical data regarding students, faculty, examination, fee packages and admissions will be collected. 
Once real time data keeps on colonizing, it can be sliced and diced as per the requirements. Also the industry will be benefited since the outcome of education industry and its timely progress will be shared on discretion of higher authorities.

\section{CONCEPTUAL MODEL}

The development of integrated data bank for educational sector of underdeveloped countries will be done in different phases. Figure 3.1 represents the steps that will be involved in the establishment process of this data bank and the time required for the completion of each phase, whereas Figure 3.2 represents the linkages that will be created with the help of this data bank.

Figure 3.1

FRAMEWORK FOR IMPLEMENTATION OF INTEGRATED DATA BANK

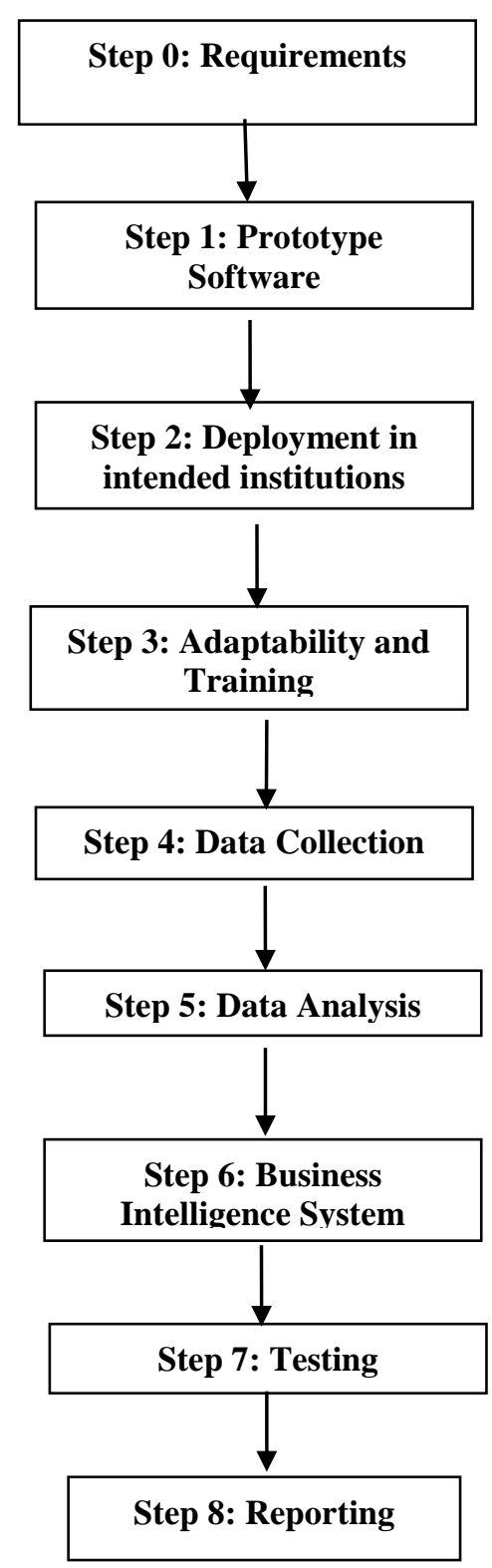


At the initial level, information relating to enrolment of students, staff, faculty and other resources of all institutions including schools, colleges, universities and other degree / diploma awarding institutes will be gathered. Available resources will be listed and a plan will be scheduled how to disseminate the information, install the system and train the staff and other stake holders. Once all the data is collected, prototype software will be developed that will be deployed for all the institutions listed in phase 1 (i.e. requirement gathering). A team of trainers for the system should be formulated that will personally deliver training to all the stake holders in formal training sessions for giving the knowledge of the system in all institutions in parts of Africa. After training of stakeholders, all the data will be populated in to the main server through which analysis can be done. Forecasting of trends can only be possible when we get real time data that is to be collected by user (stake holders) interaction with the system. BI (Business Intelligence) tool will be forecasting the trends to facilitate the stake holders as per the objective of this system. Validation and verification will be a continuous activity for the maintenance and improvement of system. Customized reports will be generated to facilitate all the stake holders.

Figure 3.2

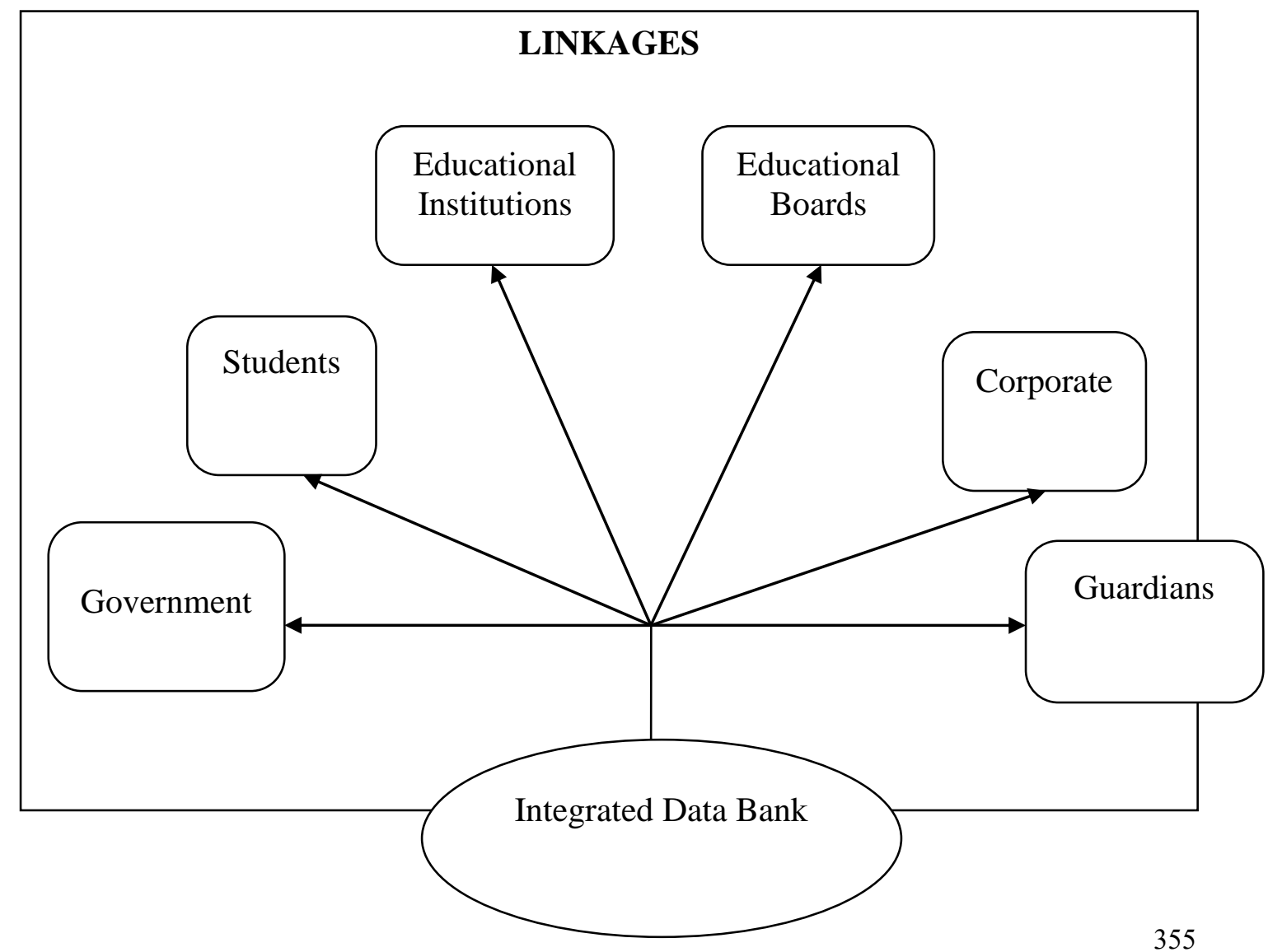


Key stakeholders of this system will be all the Educational institutions, Education Governing boards/bodies, Government of Africa, Students, Guardians and Corporate sector that will be linked through this system. Integrated data bank will facilitate all the stake holders as per their required information that can be formulated by customization of information.

\section{EXPECTED OUTCOMES}

1. Maintaining overall educational records of student that involves their attendance, marks, fee records, examination results and the curriculum taught in each course

2. Will bring Government, Educational institutions, Educational boards, Corporate, Guardians and Students on a similar platform

3. Will enable guardians to view their child's educational record on a continual basis

4. Determine trends towards different fields of specialization by generating customized reports from the system

5. Gather complete educational records of students starting from their primary level to postgraduate level studies.

6. Providing ease of monitoring to Government for progress and growth of educational sector of Africa.

7. Bridge the gap between industry and academia for fund allocation and promote the research culture across Africa.

8. Assist Government in making decisions while allocation of budget in educational sector for urban and rural areas.

9. Assist Government to keep track of the teachers and facilitators especially in public sector for Primary and Secondary Schools, Colleges and Universities in regards of their attendance.

\section{REFERENCES}

1. Balanskat, A., Blamire, R. and Kefala, S. (2006), A review of studies of ICT impact on schoolsin Europe, "European Schoolnet” 
2. Bingimlas, K.A. (2009), Barriers To the Successful Integration of ICT in Teaching and Learning Environments: A Review of the Literature, "Eurasia Journal of Mathematics, Science and Technology Education”, Vol.5(3), 235-245

3. Maignan, C.J., Ottaviano, G. I. P. and Pinelli, D. (2003), ICT, Clusters and Regional Cohesion: A Summary of Theoretical and Empirical Research, "FEEM Working Paper No.58.2003”

4. Flecknoe, M. (2002), How can ICT Help us to Improve Education?, "Innovations in Education and Teaching International”, Vol.39(4), 271-279

5. Fredriksson, U., Gajek, E. and Jedeskog, G. (2009), Ways to use ICT in schools to optimize the impact on teaching and learning, "ActaDidacticaNapocensia”, Vol.2(4), 2132

6. Gichoya, D. (2005), Factors Affecting the Successful Implementation of ICT Projects in Government, "Electronic Journal of e-Government”, Vol.3(4), 175-184

7. Holmes, B., Tangney, B., Fitzgibbon, A., Savage, T. andMehan, S. (2001), Communal Constructivism: students constructing learning for as well as with others, in J. Price, D. Willis, N.E. Davis \& J. Willis (Eds), "Proceedings of the 12th International Conference of the Society for Information Technology and Teacher Education (SITE 2001)", 31143119, 5-10 March, Orlando.

8. Jamtsho, S. and Bullen, M. (2007), Distance Education in Bhutan: Improving access and quality through ICT use, “Distance Education”,Vol.28 (2), 149-161

9. Jhurree, V. (2005), Technology Integration in Education in Developing Countries : Guidelines to Policy Makers, “International Education Journal”, Vol.6(4), 467-483

10. Kirschner, P. and Davis, N. (2003), Pedagogic benchmarks for information and communications technology in teacher education, "Technology, Pedagogy and Education", Vol.12(1), 125-148

11. Kozma, R. B. (2005), National Policies That Connect ICT-Based Education Reform To Economic And Social Development, "Human Technology”, Vol.1(2), 117-156 
12. Krishnaveni, R. and Meenakumari, J. (2010), Usage of ICT for Information Administration in Higher education Institutions - A study, "International Journal of Environmental Science and Development, Vol.1(3), 282-286

13. Leask, M. and Younie, S. (2001), Communal constructivist theory: Information and Communications Technology pedagogy and Internationalization of the curriculum, “Journal of Information Technology for Teacher Education”, Vol.10(1-2), 117-134

14. Osborne, J., and Hennessy, S. (2003), Literature review in science education and the role of ICT: Promise, problems and future directions, "London: Futurelab"

15. Richards, C. (2010), From old to new learning: global imperatives, exemplary Asian dilemmas and ICT as a key to cultural change in education, "Globalization, Societies and Education”, Vol.2(3), 337-353

16. Seely, B.E. (2003), Historical Patterns in the Scholarship of Technology Transfer, “Comparative Technology Transfer \& Society”, 1, pp. 7-48.

17. Sein, M.K. and Harindranath, G. (2004),Conceptualizing the ICT Artifact: Toward Understanding the Role of ICT in National Development, "The Information Society: An International Journal”, 20(1), 15-24

18. Tearle, P. (2004), A theoretical and instrumental framework for implementing change in ICT in education, “Cambridge Journal of Education”, Vol.34(3), 331-351

19. Thompson, M. and Walsham, G. (2010), ICT Research in Africa: Need for a Strategic Developmental Focus, “Information Technology for Development”, Vol.16(2), 112-127

20. Underwood, J. (2004), Research into information and communications technologies: where now?, "Technology, Pedagogy and Education”, Vol.13(2), 135-146

21. Watson, D. (2006),Understanding the relationship between ICT and education means exploring innovation and change. "Education and Information Technologies", Vol.11(34), 199-216 
22. Zandvliet, D.B. and Fraser, B.J. (2004), Learning environments in information and communications technology classrooms, "Technology, Pedagogy and Education", Vol.13(1), 97-12423.

23. Statista, "Number of smartphone users in South Africa from 2014 to 2021 (in millions)* “ available at: https://www.statista.com/statistics/488376/forecast-of-smartphone-users-insouth-africa/ 